\title{
ENVIRONMENTAL ISSUES OF THE LJUBLJANA URBAN REGION
}

\author{
Metka Špes \\ Oddelek za geografijo, Filozofska fakulteta Univerze v Ljubljani \\ Aškerčeva 2, 1000 Ljubljana, Slovenia. \\ e-mail: metka.spes@uni-lj.si
}

\begin{abstract}
The main environmental problems of Ljubljana urban region which are obstacle of sustainable development are presented in the paper, especially the main sources of air pollution and water manegment. Actual quality of life in urban environment is seen also in noise pollution, quality and accessibility of green areas and in traffic. On the end the article discusses the attitudes of Ljubljana residents to environmental problems and quality of life in urban region.
\end{abstract}

Key words: Ljubljana, air quality, drinking water, noise pollution, trffic, green areas, attitude of residents to environmental problems

\section{INTRODUCTION}

Looked at from the point of view of sustainable development, the present quality of the geographical environment of Ljubljana represents a developmental obstacle. However, generally speaking we have not yet reached the point of irreversible degradation of the environment or its components. Critical concentration values for $\mathrm{No}_{\mathrm{x}}$, and $\mathrm{O}_{3}$ are still exceeded from time to time, the level of emissions from motor vehicle traffic has been increasing, soil pollution from certain heavy metals (especially lead) is high, and the Ljubljanica River in the section just before it joins the Sava has been classified in the $3^{\text {rd }}$ to $4^{\text {th }}$ category of water quality. However, the data on water quality during the second half of the nineties indicate that the water pumped at Ljubljansko polje was of suitable quality as a supply of drinking water, mainly due to its high self-cleaning capacity.

\section{AIR QUALITY IN THE URBAN ENVIRONMENT}

Until the mid-seventies, Ljubljana was classified among Slovene cities with the highest air pollution, with maximum values reached during the colder half of the year. Such excessive 
pollution was due to numerous individual chimneys as well as to a thermal power plant which used coal with the high sulphur content. Natural geographic factors contributing to the pollution problem include the location of the city in a basin and frequent climatic inversions, which gave rise to an average of 140 foggy days per year. According to the data, Ljubljana is the foggiest European capital city, with the thickness of the inversion often between 200 and 300 meters. The average wind velocity is only $1.3 \mathrm{~m} / \mathrm{s}$ in January and 2.0 $\mathrm{m} / \mathrm{s}$ in May, with no wind at all occurring about 6 to 10 percent of the time (Jernej, 2000). Local winds are generated by the closed basin position and they are indirectly affected also by the city and its morphology, building types, and in particular by the heat island.

During the last two decades efforts to improve the air quality were directed primarily towards decreasing $\mathrm{SO}_{2}$ emissions and particulate matter. Average annual concentrations, which at the beginning of the eighties exceeded $200 \mu \mathrm{g} / \mathrm{m}^{3}$, or three times the maximum permissible value, decreased up until the end of the nineties to $27 \mu \mathrm{g} / \mathrm{m}^{3}$. Concentrations of $\mathrm{SO}_{2}$ differ significantly depending on the microlocation of individual monitoring sites in Ljubljana, but as a rule do not exceed 50 to $70 \%$ of the maximum permissible value.

Concentrations are exceeded only during periods of extremely unfavourable weather conditions and when the thermal power plant in Ljubljana relies heavily on domestic coal. The largest share of $\mathrm{SO}_{2}$ emissions continues to be contributed by this plant; however, the resulting pollution is still much lower than it would be if the city's buildings each had its own source of heat. A decrease in $\mathrm{SO}_{2}$ emissions from the plant was achieved by using a larger proportion of good quality, low sulphur Indonesian coal, and correspondingly less domestic coal (Vpliv ..., 1999).

$\mathrm{SO}_{2}$ emissions from general and industrial use also decreased, due mainly to the phasing out of solid and liquid fuels, which were replaced by reliance on long-distance heating networks and gas, with virtually negligible $\mathrm{SO}_{2}$ emissions. The use of coal as a heating fuel in Ljubljana has decreased from $15 \%$ to only $2 \%$ of the total over the last fifteen years, while the use of natural gas has increased significantly, from $7.4 \%$ to $29 \%$.

This change of the structure of emissions causing air pollution in Ljubljana has lessened the seasonal nature of the problem, as $\mathrm{SO}_{2}$ and smoke as characteristic winter pollutants are replaced by pollutants $\left(\mathrm{NO}_{\mathrm{x}}\right.$ and $\left.\mathrm{CO}_{2}\right)$ which are distributed fairly equally throughout the year, or by pollution in the summer season (ozone).

The share of traffic emissions is increasing: traffic contributes $50 \%$ of $\mathrm{NO}_{\mathrm{x}}$ and almost $30 \%$ of $\mathrm{CO}_{2}$ emissions. Traffic is becoming a permanent source of $\mathrm{NO}_{\mathrm{x}}$ emissions, a finding which has also been supported by measuring the concentrations at monitoring sites in the center of Ljubljana, with average annual concentrations of $75 \mu \mathrm{g} / \mathrm{m}^{3}$.

Excessive concentrations of ozone are becoming a problem of critical importance for ensuring air quality in Ljubljana. The maximum permissible limit of $\mathrm{O}_{3}$ pollution in the city was most frequently exceeded during the period from April throough August. However, pollution caused by this secondary pollutant is even greater at the city's outskirts, indicating negative effects spread from the city itself to its wider environs.

Air pollution in the city from $\mathrm{SO}_{2}$ and smoke (concentrations of the latter are even lower) is lower now than it was a few years ago, and it is also quite evenly distributed, so there are no urban areas with particularly heavy pollution, except during the exceptional 
circumstances already mentioned. The city center on the one hand, and areas in the immediate vicinity (up to 100 meters) of heavily frequented urban main roads on the other, are hot spots for air pollution resulting from traffic-related emissions $\left(\mathrm{NO}_{\mathrm{x}}, \mathrm{CO}_{2}\right.$ and ozone) (Onesnaženost...,2000).

Figure 1: Estimation of air pollution

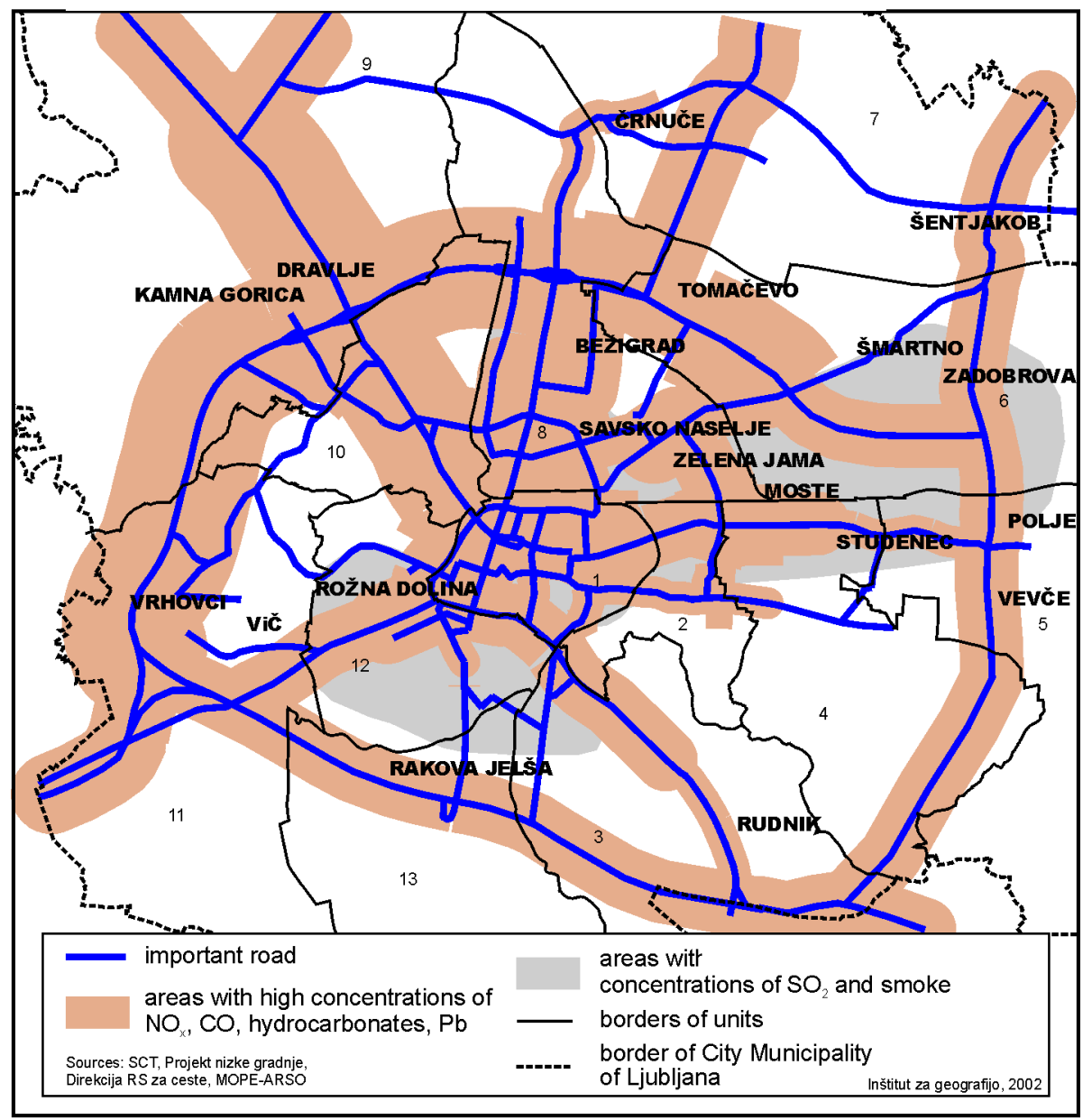

Carbon dioxide emissions, which are the main target of the Kyoto Protocol, display annual fluctuations in Slovenia, depending on the variable level of traffic-related emissions. Overall, this curve is still increasing, and has exceeded 8 tons per capita. Since 1986, when Slovenia first undertook to implement the provisions of the Kyoto Protocol), $\mathrm{SO}_{2}$ emissions in Ljubljana have increased by $22 \%$. This means that the "Kyoto value" has been exceeded by nearly $33 \%$. However, the structure of the sources of the emissions has fundamentally changed. The share of emissions from industrial sources has decreased by about $15 \%$ as a 
result of technological and consequently ecological restructuring of industrial plants, whereby solid and liquid fuels have been replaced by natural gas, and by a drop in production from economically unprofitable industrial plants. Also, $\mathrm{CO}_{2}$ emissions originating from general consumption have decreased by almost $16 \%$, since long-distance heating and use of natural gas has become more and more frequent in the city during this period. $\mathrm{CO}_{2}$ emissions originating from a major source in Ljubljana-the thermal power plant-are also slowly decreasing, but these reductions have been more than offset by a $72.8 \%$ increase (Gasperič, 2000) in the quantities of emissions produced by traffic over the past fifteen years, due to the rapidly increasing dependence on automobile transportation, especially over the past decade.

Graph 1:Proportions of emissions of $\mathrm{CO}_{2}, \mathrm{SO}_{2}, \mathrm{NOx}$ and solid particles by major sources of pollution

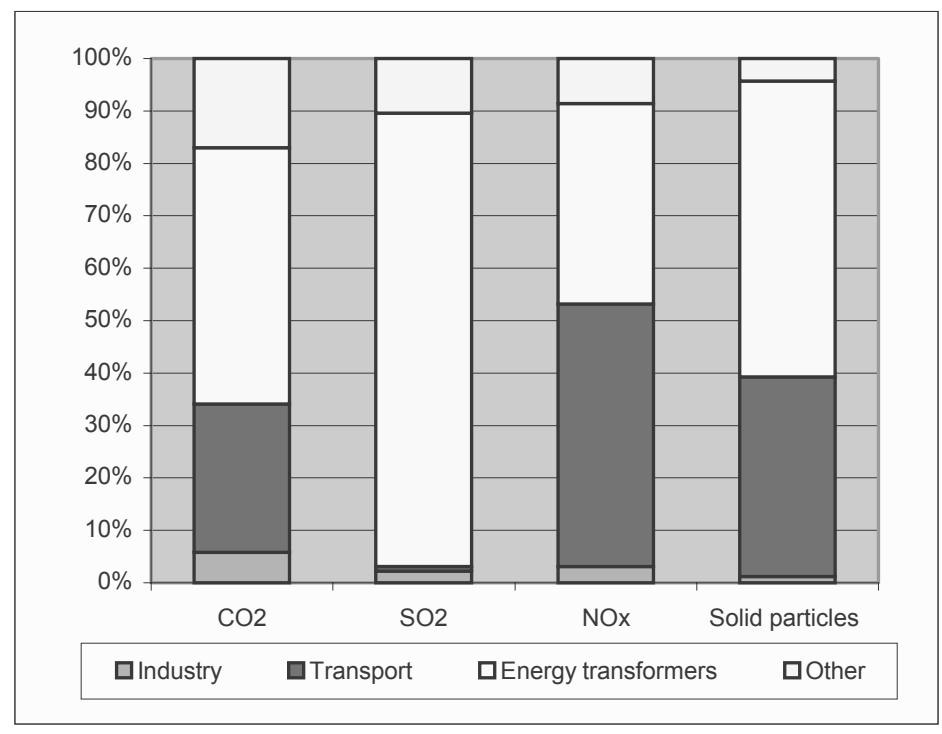

Table 1: Proportions of emissions of $\mathrm{CO}_{2}, \mathrm{SO}_{2}, \mathrm{NO}_{x}$ and solid particulate matter from major sources of pollution in 1998.

\begin{tabular}{|l|r|r|r|r|}
\hline Sector & $\mathrm{CO}_{2}$ & $\mathrm{SO}_{2}$ & $\mathrm{NO}_{\mathrm{x}}$ & Solid particles \\
\hline Industry & 5.8 & 2.2 & 3.1 & 1.2 \\
\hline Transport & 28.3 & 0.9 & 50.1 & 38.1 \\
\hline Energy transformers & 48.9 & 86.6 & 38.2 & 56.4 \\
\hline Other & 17.0 & 10.4 & 8.6 & 4.3 \\
\hline
\end{tabular}

Source: Inštitut za energetiko..., 1999.

On the basis of the results of both foreign investigations and a comparative analysis of the data during times of increased air pollution in Ljubljana, as well as drawing on public 
health data, we can conclude that an increased number of emergency room visits from patients with aggravated chronic pulmonary disease and from people seeking treatment for acute respiratory diseases coincides with the days when the maximum permissible 24-hour concentration of $\mathrm{SO}_{2}$ is exceeded. Furthermore, concentrations, which exceeded the onehour maximum permissible, results in an increased incidence of asthmatic attacks and aggravates the condition of asthmatic patients. Judging from the results of foreign investigations, it can be anticipated that the number of respiratory diseases in children and physically active adults will continue to increase in Ljubljana during days of increased ozone concentration (presumably by 20-30\%). Swiss studies show a 30\% increase in respiratory system diseases of children exposed to environments which exceeded the maximum permissible concentration over a period of eight hours. Ozone measurements in Ljubljana show that there are about 40 days during the summer months when concentrations exceeded the maximum permissible level over eight hours (Otorepec, Letnar-Žbogar, 1997).

\section{WATER MANAGEMENT}

More than 27 million $\mathrm{m}^{3}$ of water are consumed in Ljubljana per year, of which more than 10 million $\mathrm{m}^{3}$ are consumed by industry (water for cooling not included) and about 16 million $\mathrm{m}^{3}$ by households. The use of water increased rapidly in the past decades (from 4 million $\mathrm{m}^{3}$ in 1940). The greatest consumption was registered in 1987 with 33.9 million $\mathrm{m}^{3}$, but after this year a slight decrease was observed due to a lower consumption by industry (Brečko, 1996). However, the losses amount to between 46 and 50\% of the pumped water, so that the quantities of groundwater withdrawals were actually much greater than the yearly consumption or the quantity of water sold. The central water supply system supplies drinking water to $97 \%$ of all buildings in the city. The pumped water at the water station mainly meets the basic requirements and standards, but this cannot be said of all the water by the time it reaches consumers. The drinking water of consumers may be of poorer quality depending on the quality of water mains, their maintenance and their construction material. If any flaws appear in water mains, a greater concentration of lead or even microbiological pollution may occur.

The consumption of drinking water in Ljubljana is $1500 \mathrm{l} / \mathrm{sec}$; it is withdrawn from the reserves of two aquifers, one in the Ljubljansko polje plain and another in the fan of the Iška River (Brečko, 1998), which together have enough water reserves to satisfy water needs at present. The groundwater of Ljubljansko polje with its exceptional environmental and developmental strategic extension probably represents the most important natural water source for Ljubljana. Preserving the quantity and quality of groundwater of Ljubljansko polje, and of Ljubljansko barje as a potential source, is a top priority task of the municipal political leadership.

Only two thirds of all water consumers are connected to the sewerage system of Ljubljana, because of a widespread suburbanisation pattern, illegal housing construction, and some other factors. The net result is that about 9 million $\mathrm{m}^{3}$ of wastewater per year are not properly treated. Environmental threats to a safe and healthy supply of drinking water to 
Ljubljana include intensive land use, urban and suburban sprawl, improperly managed sewage flows, shopping centers, warehouses, and highway bypasses and a resulting increase in the density of traffic on Ljubljansko polje (Brečko Grubar et al., 2000). The northern part of Ljubljana is mostly situated in areas of water protection. Half of all houses are not connected to the sewerage system, and the sewerage main is aging (Okolje v MOL, 2000). Widespread small business and industrial zones, constructed in the sixties and seventies within the narrower water-protection area due to economic interests in disregard of the warnings of environmental experts, represent the biggest problem. Also sited in waterprotection areas are 1900 ha of arable land with mostly intensive, market-oriented crop production. Water-protection areas are cut by highways, bypasses and other roads. According to Kušar (2000), 187, or 52\%, of all illegal garbage dumps of Ljubljansko polje are situated in areas which are supposed to be under a groundwater protection regime. The greatest total daily burden on the environment from wastewater produced by industry, households and other activities at the outlet to the Central Processing Plant of Ljubljana (hereinafter: CPP) amounts to 830,000 PU (population units). All wastewater collected in the combined central sewerage system drains towards the CPP, which is located at the confluence of the Sava and the Ljubljanica Rivers.

For the time being, only the mechanical stage of processing has been developed at the CPP, with a capacity of $360,000 \mathrm{PU}$; the second stage of processing (biological) is under construction. In addition to the CPP, there are also five smaller local treatment plants in the municipality.

The results of analysed water samples taken at the pumping stations which supply drinking water to Ljubljana show that the quality of pumped water throughout the year depends on the height of the water table and precipitation amounts; nevertheless, the water is suitable, because $85 \%$ of the pumped water need not be chlorinated. The quality of drinking water in Ljubljana is generally adequate, and there are but few European cities of such size with the possibility to pump quality drinking water from the Quaternary alluvium in a larger area of the town. Only some physical-chemical parameters were problematic in the drinking water of Ljubljana, while the results of microbiological tests of water samples met the criteria for drinking water (Okolje v MOL, 2000).

\section{NOISE POLLUTION OF THE URBAN ENVIRONMENT}

Several measurements of noise made in 1995, 1996 and 2001 (Špes et al, 1995, Špes et al, 1997, Špes et al 2000) as well as the opinion of residents show that noise is a critical environmental problem in the present residential environment. Traffic is a major source of noise, and causes a variety of different noise pressures on the environment. Noise decreases rapidly with the distance from the source; the presence of physical obstructions (e.g. buildings) between the source and the observation point is also important. Some of the more important findings with respect to noise pollution in Ljubljana (Špes et al., 2002) are as follows: 
- At 56 locations (of a total of 112 locations, i.e. 50\% of measurements) the measured noise $\left(\mathrm{L}_{\mathrm{d}}\right)$ was higher than $60 \mathrm{~dB}(\mathrm{~A})$ which is, according to the Decree on Noise in the Natural and Residential Environment, at the upper tolerable limit for noise in the residential environment;

- At 15 locations the measured noise was even higher than $70 \mathrm{~dB}(\mathrm{~A})$ which is the upper tolerable limit for the IVth stage of noise protection areas. These values were measured at locations in the very center of the city, in the direct vicinity of main roads and bigger crossroads;

- Noise between 65 and $70 \mathrm{~dB}(\mathrm{~A})$, which is still not suitable for the residential environment, occurs at several locations in the city center (see the map) and within a wider range along the urban main roads. Such noise is also typical of numerous, mainly residential streets with heavier traffic;

- The measured noise between 60 and $65 \mathrm{~dB}(\mathrm{~A})$ is mainly above the acceptable and, according to the Decree, tolerable limits. These values were measured at 26 locations, most of which lie in residential districts or their edges. In these cases, too, traffic was the main source of noise.

The measurements of noise levels or computer models do not necessarily convey the full extent to which a certain noise is actually disturbing to the surroundings or the people who are affected by it, since noise perception has a highly subjective component.

A survey of Ljubljana residents in 2001 showed that noise was disturbing to a great percentage of them. Even though the respondents' most frequent answer was that noise disturbed them mainly in the daytime, there was only a slightly smaller number of those who answered that noise disturbed them mainly at night. Moreover, for one fifth of the interviewed persons noise was disturbing both day and night.

The results of the survey show that road traffic is an important source of disturbing noise in a greater part of the Ljubljana area. A concentration of answers citing road traffic as the most disturbing occurred along the more frequented roads - the motorway or the Ljubljana ring road is less problematic due to its spatial isolation, partial noise protection and position at a lower level - and in a greater part of the city center. Other sources of noise (production plants, parking areas, sites of various events, etc) are point sources and therefore it was not possible to include them systematically in the survey.

Some activities or institutions (hospitals, kindergartens, schools and the like) are more sensitive to noise than the average. Special attention in the investigation was paid to elementary and secondary schools. Therefore the survey was also conducted at schools; the results show that the locations of elementary schools were chosen more carefully from the aspect of noise pollution than the locations of secondary schools, which are mainly located in the very center of the city, right by major traffic routes.

One of the more important aims of the investigation was also to identify the areas that are more favourable from the aspect of noise pollution, and those that are less favourable. Because of the specific character in the expansion of this environmental problem, well determined, discrete areas of specific noise intensity were not formed, but only varied and fragmented spatial models of areas in which noise is more or less perceptible. 
Figure 2: Areas of Ljubljana in regard to the prevalling state of noise pollution (Estimation on the basis of the results of noise measurements, idensity of traffic and results of questionnaire survey)

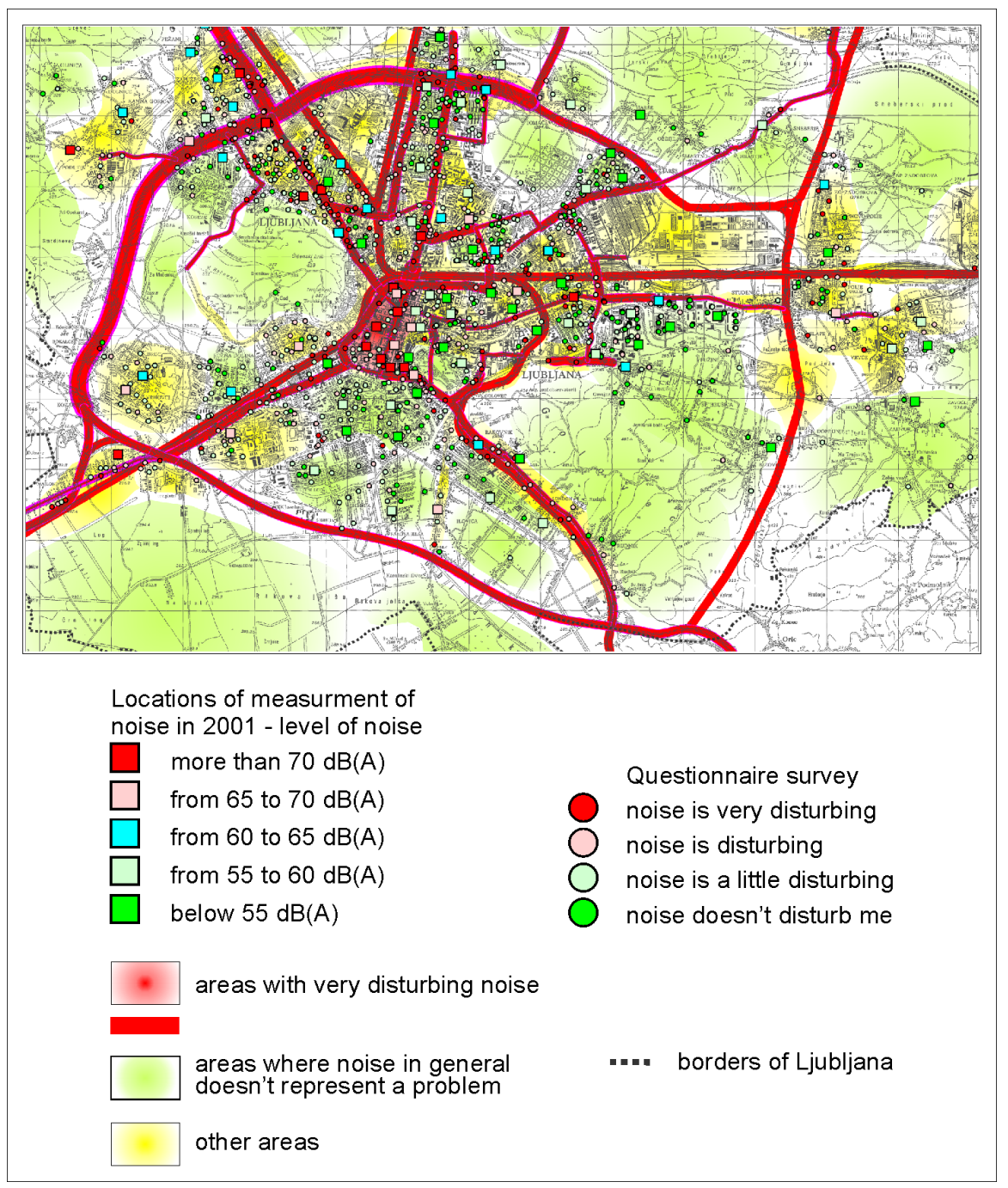

Areas classified as having above-average noise pollution were the following:

- the wider area of the city center where transport is combined with a number of various service activities;

- the areas along the busiest roads; the width of these zones along the roads differs, depending on the traffic load and the presence and location of various buildings along the roads. In general, the roads with a daily traffic density over 20,000 vehicles were explicitly problematic with respect to noise pollution; 
- the areas along the railways, which are rather narrow, yet the intensity of noise coming from railway transport is above average and occurs day and night, although the noise decreases somewhat at night;

- point sources of noise: production plants, restaurants, bars, sites and halls for events, churches, playgrounds and the like (Špes et al., 2002).

The identification of the noisiest areas has shown that nearly 50,000 residents of Ljubljana, or about one fifth of its total population, live in these areas.

\section{TRAFFIC CONGESTION IN THE CITY}

Of all the sources of noise pollution, traffic contributes the greatest portion of noise in urban areas - as much as $60 \%$ - and in recent years it has also been a major and growing source of air pollution. It has become increasingly difficult to control its intense growth.

In 1996, there was one car per 2.46 inhabitants of Ljubljana, for a total of 10,875 vehicles registered. By 2000 the number had increased by $12 \%$ overall, and by $23 \%$ in the city center. 840 ha in Ljubljana were used for road infrastructure, of which $98 \%$ was for roads and parking. $65 \%$ of workers rely on motorized transport (buses or cars) for their daily commute (as compared to $45 \%$ in 1970), while $31 \%$ walk or bicycle (MOP, 1998). Every day at least 35,000 inhabitants of the urban region of Ljubljana travel to work by car, resulting in 25,000 cars traveling from the suburbs to the city each day (Gabrovec et al., 2000). Due to the poor organisation and usage of public transport, the city itself is becoming more and more congested with traffic.

Despite a marked increase in traffic on the Ljubljana ring road, congestion on the urban main roads and in the very center of the city still remains Ljubljana's most acute problem. The average daily frequency in the city's streets is 20,000 to 30,000 vehicles, which already poses a great problem to smooth circulation of traffic (Podatki o registriranih vozilih....,2000).

The increasing density of traffic in Ljubljana obstructs the circulation of vehicles in the city, since the average annual traffic increase on the urban main roads was as much as 5.1\% already in the 1989-1994 period. In the most recent period, this growth has slightly diminished, but traffic remains one of the key problems in the city. The ideal solution would be to encourage commuters to reduce their dependence on automobiles and turn instead to the public transport system, but unfortunately the latter has become increasingly less popular over the last decade. Only very recently, stimulated in part by the stricter parking regime in the city center, have people gradually begun to get used again to the very practical and environmentally least problematic public transport.

As a rule, buses use the same roads as cars, but their travel time is up to $30 \%$ longer compared to travel by car. In spite of the fact that bus stops are easily accessible $(90 \%$ of city residents live less than 500 meters from a bus stop), the role of buses is slowly decreasing. During the last ten years, the number of bus passengers has decreased by almost a third. Špes et al, 1997) 


\section{GREEN AREAS}

In spite of a quite favourable general proportion between open space and built-up areas, typical city green areas are not very frequent, and about one third of Ljubljana residents live more than 500 meters from such areas. However, the biggest part of agricultural areas, allotments and other private green spaces, not accessible to the general public, are situated in Ljubljana. Ljubljana is characterised by large areas of mostly natural environment (wedge-shaped) practically inside the city center. However, the fragile ecosystemic connection between the urban and rural (agricultural and forestry) environments of Ljubljana has been severed by new motorways ringing the city

Figure 3: Answers to the question: "Are you satisfied with the environment in wich you live?"

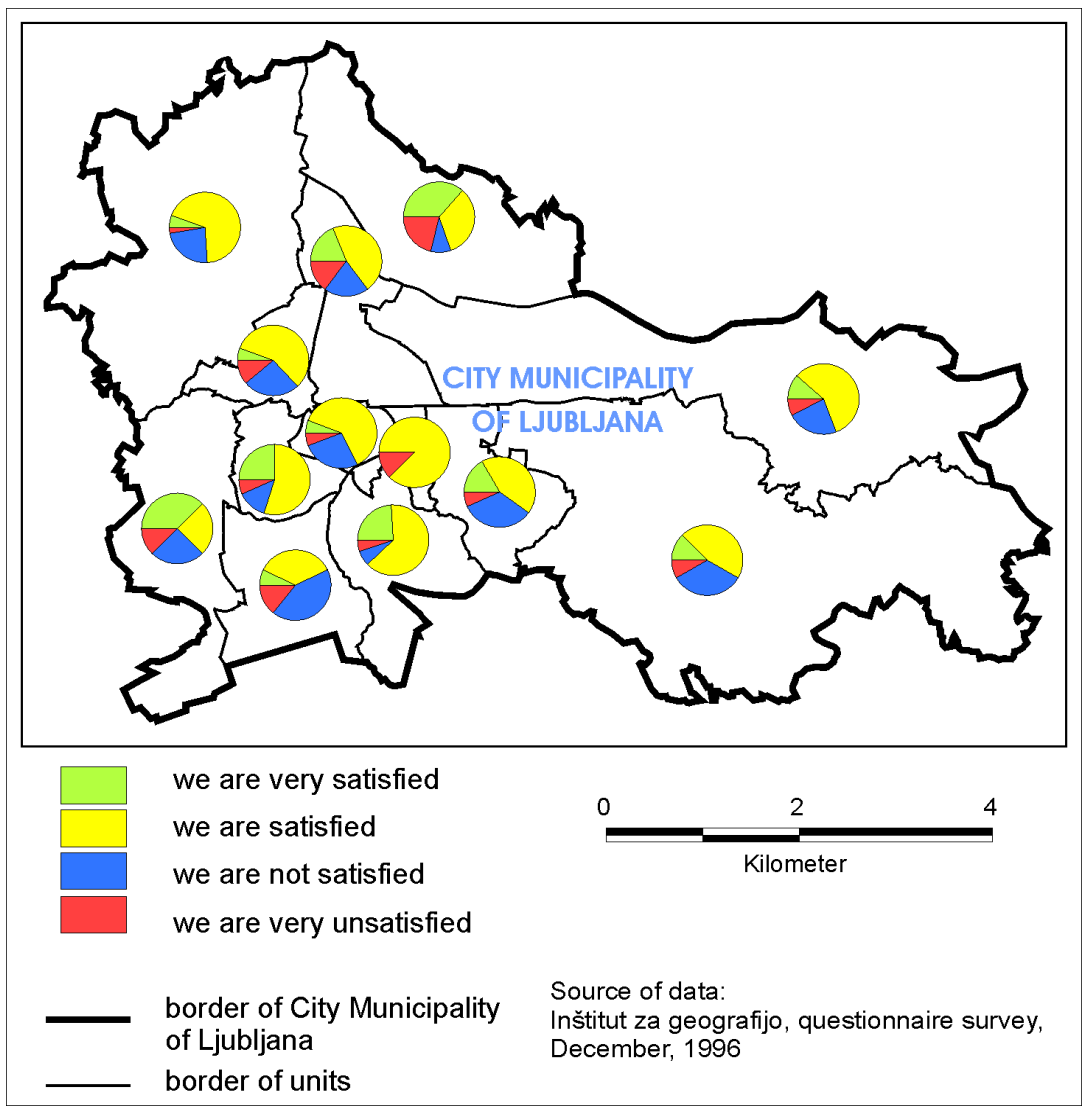

Much more problematic than the size of green areas in Ljubljana - more than $25 \mathrm{~m}^{2}$ per capita - is their structure. Urban planning criteria have set a standard of 25 to $45 \mathrm{~m}^{2}$ of green space per capita for urban residential environments. However, the accessibility of green spaces is what has a decisive impact on the quality of the residential environment and 
the satisfaction of the urban population (Ogrin, 1994). In our investigation, a distance of 500 meters was taken as a criterion for good accessibility. $65 \%$ of Ljubljana residents live within this distance to green spaces. Green areas with public access were taken into consideration, from parks and organized green areas in the city center to meadows and forests at the outskirts of Ljubljana, where their primary function is mainly recreational and environmental, not economic (Špes et al, 2000).

\section{ATTITUDES OF LJUBLJANA RESIDENTS TO ENVIRONMENTAL PROBLEMS}

Humans simultaneously cause and suffer from negative spatial and environmental impacts. They adjust to them or respond to them in different ways. Based on the perception of the environment, reactions occur and decisions are made that depend on numerous factors and in turn induce new changes in the environment in the majority of cases.

Attitudes of Ljubljana residents towards their residential environment was established (Špes et al, 2000) through a special survey which included 598 citizens older than 15 years. The results show that half of the respondents are satisfied with the environment they live in.

A comparison of the answers in relation to the age of the respondent shows that younger people ( 15 - 31 years) are much more critical of the environment; they also believe that no essential improvement of the quality of the residential environment has been made during the last 10 years and that, on the contrary, environmental pollution in Ljubljana has even increased. On the other hand, older people notice and perceive that environmental pollution has decreased considerably in the last 10 years.

Most respondents, regardless of the part of town they lived in, cited "air pollution and noise" as most disturbing to them. They also believe that it is not only a major problem for their own environment, but also for the whole of Ljubljana. In addition, the city suffers from badly polluted streams and poorly organized waste management (the problem of waste sorting and bad smells that spread from the landfill at Ljubljansko Barje). They consider Ljubljana and long-distance heating plants as well as traffic to be major sources of emissions, and also industrial plants in some of the urban parts. People also believe that industry (and, to a lesser extent, municipal wastewater) is the main culprit for pollution of streams and groundwater, and noise.

The respondents were of the opinion that air pollution and noise have increased in the last ten years due to the increased number of cars. They propose that the construction of the Ljubljana ring road be completed as soon as possible in order to carry transit traffic, while greater use of public transport could reduce local traffic (they wish that buses would run more frequently). In their opinion both local and long-distance thermal power plants should install more efficient filters or completely replace domestic coal with environmentally less damaging imported coal, which is also more energy-efficient. Some individuals also suggested the use of natural gas in place of coal. 


\section{CONCLUSION}

In reviewing some environmental indicators of sustainable development for Ljubljana, we have pointed out some of the positive measures taken to reduce the city's air pollution (use of natural gas as a heating fuel, long-distance heating, the import of quality coal). On the other hand, there have been significant setbacks in wastewater management and solid waste disposal, which have been set as major environmental priority tasks to be completed by 2005. City administration also set basic strategic sustainable tasks such as containing urban and suburban sprawl, ensuring that the residential function remains one of the city center's functions, managing road traffic and preserving the quality of drinking water from Ljubljansko polje (Plut, 2000).

Looked at from the perspective of sustainable development, the following environmental pressures in and around Ljubljana require immediate attention: the increasingly heavy traffic congestion in the city, the growth in personal consumption and related increase in the production of waste, and sprawl, especially around the groundwater areas of Ljubljansko polje. A top priority for the city in formulating a sustainable transportation policy should be to make public transport more attractive to residents, while in the medium run decreasing the need for motorised traffic by encouraging policies that shorten commuting distances, improve telecommunication networks, expand the network of bicycle paths, and so on. Moreover, steps need to be taken to preserve the quality of groundwater in Ljubljansko polje, first of all by decreasing environmental pressures from land use and sources of environmental burdening (e.g. illegal waste dumps in areas of water protection). Nothing less than an across-the-board modification of city policies to align them with the principles of sustainable development is needed, especially in the areas of transport, waste management, water management and urban planning.

\section{Reference}

Brečko Grubar V., Kušar, S., Plut D., 2000: Regionalna vloga in pokrajinska obremenjenost talne vode Ljubljanskega polja, Ljubljana-geografija mesta, Ljubljana, s. 175-184.

Brečko V. 1996: Podtalnica Ljubljanskega polja, Najpomembnejši vodni vir za oskrbo Ljubljane, geografski vestnik, 68, Ljubljana.

Brečko V., 1998: Vpliv pokrajinsko ekoloških dejavnikov na vodno oskrbo Ljubljane, Magistrsko delo, Filozofska fakulteta, Oddelek za geografijo,Ljubljana.

Gabrovec M., Pavlin B., Sluga G., 2000: Dostopnost do javnega potniškega prometa v Ljubljanski regiji, Ljubljana-geografija mesta, Založba ZRC, Ljubljana.

Gasperič M., 2000, Pogoji za uresničevanje v kyotskem protokolu opredeljenih ciljev glede varstva zraka, raziskovalno poročilo, Ljubljana.

Inštitut za energetiko (Energy Institute), 1999: Spremljanje izvajanja energetske bilance v mestu Ljubljana v letu 1998 in izračun emisij škodljivih snovi (Monitoring the energy balance in the city of Ljubljana and calculating the emissions of pollutants), Ljubljana Jernej S., 2000: Mestna klima, Ljubljana-geografija mesta, Založba ZRC, Ljubljana. 
Kušar S., 2000: Geografske značilnosti odlagališč odpadkov na Ljubljanskem polju, Diplomska naloga, Filozofska fakulteta, Oddelek za geografijo, Ljubljana.

Ogrin D., s soavtorji, 1994: Zeleni sistem Ljubljane, zasnova, Biotehniška fakulteta - Inštitut za krajinsko arhitekturo, Ljubljana.

Okolje v mestni občini Ljubljana, 2000: Zavod za varstvo okolja, Ljubljana.

Onesnaženost zraka v Sloveniji v letu 1998, 2000: Hidrometeorološki zavod Republike Slovenije.

Ortorepec, P., Letnar-Žbogar, N., 1997: Bolezni in bolezenska stanja, za katere je dejavnik tveganja slabša kvaliteta bivalnega okolja-v študiji: Vpliv fizičnega in družbenega okolja na zdravje prebivalstva v mestu Ljubljana, Inštitut za geografijo, Ljubljana.

Oskrba s plinom v Ljubljani, 1996: Javno podjetje Energetika Ljubljana, Ljubljana.

Plut D., 2000: Večja mesta Slovenije kot okoljsko problemska območja, Geographica Slovenica 33/1. Ljubljana, s. 219-245.

Podatki o oskrbi z vodo in odvajanju ter čiščenju odpadnih voda, 2000: Javno podjetje Vodovod Kanalizacija, Ljubljana.

Podatki o registriranih vozilih za leto 1996, 1997: Ministrstvo za notranje zadeve, Ljubljana.

Podatki o registriranih vozilih za leto 2000, 2000: Ministrstvo za notranje zadeve, Ljubljana.

Špes M., Lampič B., Smrekar A. 1995: Kulturni in ekonomski pogoji pri oblikovanju odločitev za uravnotežen razvoj mest - Ljubljana, Inštitut za geografijo, Ljubljana.

Špes M., s soavtorji 1997: Vplivi fizičnega in družbenega okolja na zdravje prebivalstva v mestu Ljubljana, Inštitut za geografijo, Ljubljana.

Špes M., Cigale D., Gspan P., Jug A., Lampič B., 2002: Regionalizacija Ljubljane z vidika hrupne obremenjenosti (Karta hrupa na osnovi obstoječih (in nekaterih dodatnih) meritev). Inštitut za geografijo, Ljubljana.

Špes, M., Lampič, B., Smrekar, A.A., 2000: Kvaliteta bivalnega okolja v Ljubljani, Inštitut za geografijo, Ljubljana.

Vpliv TE-TO Ljubljana in JP energetika Ljubljana na onesnaženost zraka v Ljubljani, leto 1998 1999: Elektroinštitut Milan Vidmar, Ljubljana. 